\title{
On playing the Nazi card
}

\section{Professor Robert N Proctor}

Schneider and Glantz in this issue (see page 291) chronicle the industry's longstanding efforts to characterise tobacco control as "Nazi" or "fascist". ${ }^{.}$The industry's rant has a certain superficial plausibility: the Nazis had one of the world's strongest anti-cancer campaigns, one central feature of which was to curtail tobacco use. Hitler himself stopped smoking in 1919, throwing his cigarettes into the Danube in an act of defiance he later credited for helping the triumph of Nazism. The three main fascist leaders of Europe (Hitler, Franco and Mussolini) all eschewed tobacco, whereas Roosevelt, Stalin and Churchill all were avid smokers. ${ }^{2}$

The tobacco industry finds such facts useful, which is why the front group FOREST (Freedom Organisation for the Right to Enjoy Smoking Tobacco) once offered my 1988 book, Racial Hygiene: Medicine Under the Nazis, for sale as "vital" for understanding "the statist and paternalist world view of the Nazis" and "the health fascism of contemporary anti-smoking and 'health' lobbies". ${ }^{3}$ Schneider and Glantz rightly conclude that the industry's interest in such matters has nothing to do with German history, nor with the realities of fascism, but rather with an opportunistic effort to do whatever it can to keep selling cigarettes.

The industry's reductio ad Hitlerum is superficial, and ahistorical. The Nazis excelled at rocketry-does this mean that the Apollo mission was ballistic fascism? Many Nazis urged fitness and health through exercise: is jogging therefore athletic fascism? The fact that healthful or progressive policies were occasionally endorsed by the Nazis does not mean they are inherently fascist or oppressive.

The industry and its allies push the Nazi analogy, but they never probe it very far. They never point out that the German cigarette industry collaborated closely with the Nazi government (in confiscating tobacco firms in occupied territories, for example), or that tobacco taxes provided a massive source of revenue for the Nazi state. They never point out that the "Brownshirts" had their own brand of cigarette-the "Sturm-Zigarette" —or that

Correspondence to: Professor Robert N Proctor, Stanford University, History Department, CA 94305 , USA; rproctor@stanford.edu tobacco taxes helped prop up the Nazi state (more than half of all storm-trooper income, for example, was from tobacco taxes). ${ }^{2}$ They never point out that while Nazi authorities tried to curtail smoking, the industry was already powerful enough to resist most of these encroachments. The fact is that the Nazi war on tobacco was never waged as effectively as, say, the destruction of the Jews. Cigarettes were distributed to German soldiers throughout the war, and cigarettes were still being shipped to concentration camps as late as the spring of 1945. Advertising bans were imposed, along with bans on smoking in certain indoor spaces (notably Nazi party offices), but cigarette consumption actually grew throughout the first eight years of the Third Reich, until war pressures finally caused a decline. ${ }^{2}$

Schneider and Glantz are right to see the charge of "health fascism" as simply one among many rhetorical tricks used by the industry to try to marginalise public health advocacy. Arguments of this sort can, in fact, already be found in the 1930s, when the German tobacco industry ridiculed anti-tobacco activists as "fanatic psychopaths", "ascetics" and "Muradistin", with the latter term recalling Sultan Murad IV of Turkey's Ottoman Empire, said to have put to death anyone caught smoking. German tobacco manufacturers also defended themselves by setting up the Tobaccalogia medicinalis and other bodies to sow the same kind of scientific doubt later coughed up by Hill \& Knowlton and the Tobacco Institute. One interesting difference: Nazi health authorities recognised this as a sham and forced the closure of the Tobaccalogia medicinalis soon after its formation. ${ }^{2}$

The health fascism charge is only part of a much larger effort by the industry to marginalise tobacco prevention as prudish, puritanical, or otherwise foolish, fanatic and antiquated. In a forthcoming book ${ }^{6} \mathrm{I}$ list some of the many expressions used by the American industry to denigrate the science demonstrating tobacco hazards, including: "Astounding", "unwarranted, absurd" (1945); "colored by prejudice" (1945); "crude experimentation", "mere opinion" (1945); "at best, only suggestive" (1955); "nothing new" (1957); "opinions of some statisticians" (1957); "biased and unproved charges"
(1959); "scare stories" (1959); "time-worn and much-criticized statistical charges" (1959); "extreme and unwarranted conclusions" (1959); "foggy thinking" (1962); "a rehash of previously inconclusive findings" (1962); "the easy answer to a complex problem" (1962); "fanciful theories" (1964); "propaganda blast" (1964); "statistical volleyball" (1965); "utterly without factual support" (1965); "exaggerations and misstatements of fact" (1967); "guilt by association" (1968); "guesses, assumptions, and suspicions" (1968); "worse than meaningless" (1969); "claptrap" (1969); "a bum rap" (1969); "colossal blunder" (1970); "one of the great scientific hoaxes of our time" (1970); "claims of the anti-cigarette forces" (1971); "repeated assertion without conclusive proof" (circa 1971); "misinformation" (1972); "conventional wisdom" (1974); "speculations, and conclusions based on speculations" (1978); "weak conjectures based on questionable assumptions" (1979); "unproved charges, exaggerated conclusions and largely onesided interpretations of statistical data" (1979); "half the story" (1981); "dogmatic conclusions" (1982); "Orwellian 'Official Science'," "scientific malpractice" (1984); "outrageous claims" (1995); "statistical jiggery pokery" (1995); "bogus statistics" (1995); etc.

The "health fascism" charge posits tobacco control as totalitarian, but it also taints it as deeply antiquarian. That has long been a goal of the industry, to have tobacco health harms seem like "old news", stale. Tobacco control advocates are denigrated as "modern Carry Nations in science", ascetic drudges, fuddy-duddy party-poopers. The explicit goal of RJ Reynolds's Project Breakthrough from 1994, for example, was to launch a "massive, unprecedented public relations blitz" tying anti-tobacco activism to 1920s-style prohibition. The idea was to link modern public health activism to this "puritanical wave to infringe, to restrict and possibly to eliminate personal freedoms".

The target of such epithets changes over time, of course, and Schneider and Glantz rightly note that the "health fascism" charge has most often been deployed, especially in recent years, to counter efforts to reclaim clean air for the commons. One key rallying point was the epidemiological demonstration, in the early 1980s, of significant health harms from secondhand smoke. The industry responded by organising a propaganda campaign identifying smoking essentially as a form of free speech. Free flags and 
copies of the US Bill of Rights were distributed, and critics of public smoking were identified as champions of illiberalism. This new libertarian alliance allowed the industry to attack efforts to ban smoking indoors as statist and discriminatory, and a great deal of effort went into trying to identify public health advocacy with nanny-state puritanical paternalism. The industry also fostered historical research bolstering the revisionist myth that tobacco's critics especially before the 1950s were "moralist" rather than "medical". This was yet another falsification of history, ${ }^{9}$ designed to show both the recency of medical critiques of smoking and the essentially illiberal and antiquarian nature of anti-tabagism.

Of course it is true that clean air is no guarantee of democracy, just as filth is not a form of freedom. It is wrong, however, to characterise anti-tabagism as totalitarian or fascist. We should listen more carefully to the voices of those with tumours, and learn from them what kind of freedoms they have gained from smoking. I suspect that those on this terminal end of smoking's causal chain will have quite a different notion about what constitutes freedom, and wherein lies tyranny.

One of the great challenges of tobacco control is to come up with new and imaginative ways to think about how and where to intervene in the causal chains that lead to smoking. Visitors from another planet would probably be astonished by our willingness to tolerate mass death on a scale exceeding any other preventable cause of death. ${ }^{10}$ The strangeness of our present situation can be grasped by imagining a world in which every convenience store sold lead-coated children's toys, or sacks of asbestos with graphic warning labels covering, say, onethird of the sack. Equally odd is the fact that virtually all tobacco control efforts are directed at preventing consumption rather than preventing production. The industry has managed to direct most of our attention onto consumer choice (or information), leaving the means by which cigarettes are spun forth into the world unexamined, unhampered. Few people can even imagine the inside of a tobacco factory, fewer still know anything about how or where the world's cigarette-making machines are made (clue: check out the Hauni company in Hamburg). These machines cause more death and injury than any other invention in the history of humanity, but remain virtually unprobed by tobacco prevention scholars. That is the world in which we live, thanks partly to the success of the industry in framing how we talk and think about tobacco, including schemes that make smoking seem a kind of freedom.

The grand challenge for tobacco prevention (a term I prefer to tobacco control-we don't have asbestos control or lead control, and we don't control polio or smallpox) is to broaden our sense of what might be possible, and where we might intervene. And until we broaden our imagination, and the media through which it is expressed (film! contests! public art!), we should not be surprised to have the world still think of tobacco harms as "old news" and tobacco control as tyranny.

Competing interests: I have been an expert witness for plaintiffs in tobacco litigation.

Tobacco Control 2008;17:289-290.

doi:10.1136/tc.2008.026344

\section{REFERENCES}

1. Schneider NK, Glantz SA. "Nicotine Nazis strike again": a brief analysis of the use of Nazi rhetoric in attacking tobacco control advocacy. Tob Control 2008;17:291-6.

2. Proctor RN. The Nazi war on cancer. Princeton, NJ: Princeton University Press, 1999.

3. Tame CR, Elliott N. Up in smoke: the economics, ethics and politics of tobacco advertising bans. 1991, Bates TIMN 378078-8119, p 37 at 8118 .

4. Aschenbrenner H. "Forschung oder Behauptung," Deutsche Tabakzeitung, 47 (20 Nov 1940), cited in Reine Luft 1941:36.

5. Becher G. Sind Wir wirklich Muradisten? Reine Luft 1939:119-20.

6. Proctor RN. Golden holocaust: a history of the global tobacco plague (forthcoming).

7. Wade CB Jr. 13th Annual RJR supervisors meeting, health update. RJR Management Bulletin 15 (1963): No 16 p 4, Bates 500034004

8. Reynolds RJ. Project Breakthrough, 1994, Bates 513206927-6930.

9. Kyriakoudes LM. Historians' testimony on "common knowledge" of the risks of tobacco use: a review and analysis of experts testifying on behalf of cigarette manufacturers in civil litigation. Tob Control 2006;15(suppl 4):iv107-16.

10. Proctor RN. Tobacco and the global lung cancer epidemic. Nat Rev Cancer 2001;1: 82-6. 